\begin{tabular}{|c|c|c|}
\hline Beitr. Ent. & Keltern & ISSN 0005-805X \\
\hline $54(2004) 1$ & S. $241-253$ & 28.05 .2004 \\
\hline
\end{tabular}

\title{
Ethological and morphological adaptations of Psophus stridulus LINNAEUS 1758 to habitat islands
}

\section{(Caelifera: Acrididae)}

With 2 tables and 6 figures

ANDRÉ BÖNSEL

Summary

This article proposes the hypothesis that the Orthopteren species Psopbus stridulus restricted itself to habitat islands during its range expansion in the Holocene, and that it is specifically adapted to these. Literature analysis shows, that $P$. stridulus never colonises large areas, but is always concentrated in small isolated patches. Observations in Poland and Western Siberia corroborate this findings. The hypothesis is supported by the specific autecology and ethology of the species. To verify the hypothesis, a number of ethological, morphological and genetic features of this species can be understood as selective adaptations. In the context of nature conservation, these features have been discussed previously as existence-threatening trends.

Recapture experiments in an isolated habitat island in NE Poland showed, that during the imaginal stage males were highly significantly more mobile than the females. On average, the males covered distances of $20 \mathrm{~m}$, the females of $5 \mathrm{~m}$. No pattern could be detected in the males' movements, their trajectories crossed frequently. Mean size of male home range was $67 \mathrm{~m}^{2}$, and of female home range $20 \mathrm{~m}^{2}$. Usually the females sat together in clusters. If noticing approaching groups of males by their rattle, the females hid. They were discovered by few or only a single male of the group. After mating, the males left very fast, whereas the females stayed motionless on the same spot. A couple of hours or days later they could be found by another male, and another mating could take place. The discovery of the passive and hidden females might be attributed to short-time excretions of pheromones by the females in low dose. It is possible, that the females are stimulated to excrete pheromones by the rattle of the active males. Compared to females, the males have a significantly higher abundance of Sensilla coeloconica on their antennae, which serve for detection of chemical stimuli. The hidden way of life of the females, who eventually announce their presence by only short-time signals consisting in pheromones, and the high spatial dynamics of the males increase the chance, that more than one male mates with a female, or a male with a number of females, respectively. Besides to the extraordinary unbalanced sex-tatio of $P$. stridulus, and the females' ability to store sperm, which were already described in the literature, this paper shows further adaptations for the survival of a species occurring only in habitat islands. For verification of the hypothesis, further investigations to confirm the excretion of pheromones by females, and on the functions of the sensilla are necessary, as well as studies on physiological plasticity of the females, enabling directed investment in an increased proportion of male offspring.

\section{Zusammenfassung}

Nach Analyse der Literatur und der danach festgestellten punktuellen Verbteitung von Psophus stridulus wurde die Hypothese aufgestellt, dass sich diese Orthopteren-Art während der holozänen Ausbreitung auf Habitatinseln beschränkte und diesbezüglich Adaptationen bestehen. Zur Verifikation liessen sich schon vor dieser Studie verschiedene ethologische und genetische Kenntnisse zut Art als selektive Adaptationen zusammentragen, wenngleich sie bislang als existenzbedrohende Trends diskutiert wurden. 
Wiederfangexperimente zeigten auf einet weiträumig isolierten Habitatinsel im nordöstlichen Polen, dass die Männchen während der Imaginalphase hoch signifikant aktiver als die Weibchen waren. Die Männchen legten durchschnittlich $20 \mathrm{~m}$ und die Weibchen $5 \mathrm{~m}$ zurück. Die Bewegungen der Männchen kreuzten sich ständig in einer imaginären Fläche, wobei der mittlere Aktionsraum eine Fläche von $67 \mathrm{~m}^{2}$ umfasste. Dahingegen waren die Weibchen ortstreu und bewegten sich im Durchschnitt auf einer Fläche von $20 \mathrm{~m}^{2}$. Insbesondere bei sich nähernden erhöhten Männchenaktivitäten versteckten sich die Weibchen. Schließlich fanden immer nur einzelne Individuen aus den männlichen Pulks ein Weibchen. Das Auffinden der passiven und versteckten Weibchen wird auf kurzzeitige und gering dosierte Ausscheidungen weiblicher Pheromone zurückgeführt. Denkbar wäre, dass die Weibchen vom Schnarten der aktiven Männchen stimuliert werden und Pheromone produzieren. Auf den männlichen Antennensegmenten ließ sich eine hoch signifikant höhere Abundanz von Sensilla coeloconica gegenüber den Weibchen diagnostizieren, welche für solche chemischen Reizwahrnehmungen fungieren können. Die versteckte Lebensweise der Weibchen mit möglicherweise nur kurzen Anwesenheitssignalen durch Pheromone und die gleichzeitig chaotische Dynamik der Männchen erhöht die Chancen, dass mehrere Männchen sich mit einem Weibchen bzw. ein Männchen mit mehreren Weibchen paaren. Neben den schon in der Literatur beschriebenen außergewöhnlichen Geschlechterverhältnis von Männchen/Weibchen und der Spermienspeicherung konnten nunmehr weitere eindeutige Adaptationen zur Erhaltung der genetischen Vielfalt für das Übetleben einer inselartig vorkommenden Att aufgezeigt werden. Zur weiteren Verifikation der Hypothese wären Untersuchungen zur Bestätigung weiblicher Pheromonausscheidungen, zur Funktionalität der Sensillen und physiologischer Möglichkeiten zur gesteuerten weiblichen Investition in mehr männliche Nachkommen erforderlich.

\section{Key words}

Psophus stridulus, habitat island, sex-specific movement pattern, sensilla sex dimorphism, adaptation

\section{Contents}

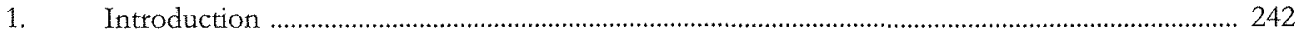

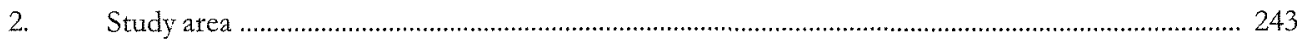

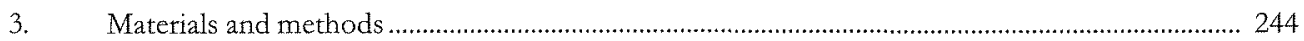

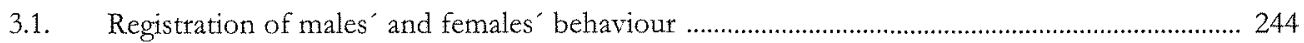

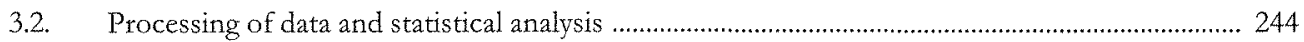

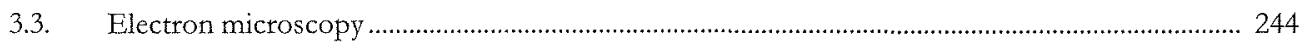

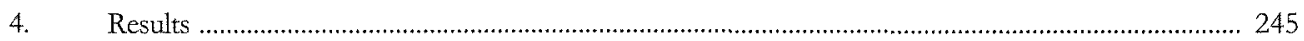

4.1. Spatial distribution and movement pattent of males and females ............................................. 245

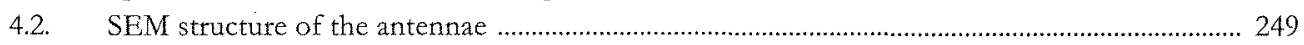

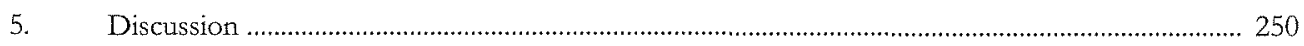

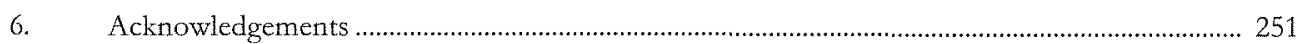

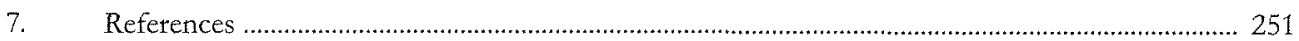

\section{Introduction}

Psophus stridulus is considered to be a well studied species among European grasshoppers (DETZEL 1998). The species has been described to colonise meso- to xerophilous habitats with plant communities characterising late successional stages which stay constant for longer time periods (VÄISÄNEN et al. 1991, HEß \& RITSCHEL-KANDEL 1992, BUCHWEITZ 1993, Kolb \& Fischer 1994, Vossen \& Piper 1996, VARGA 1997, JANBEN \& REICH 1998 , BÖNSEL \& RUNZE 2000). P. stridulus lays its eggs in the soil, but the exact require- 
ments on soil conditions are not sufficiently known. BÖNSEL \& RUNZE (2000) pointed out for Central Europe, that calcareous soils and constant water supply are common features of many habitats of $P$. stridulus. An habitat of $P$. stridulus, isolated for centuries, can be found in north-east Poland. Its conditions resemble those of the species' original habitats. The existence of these habitat islands, as well as the long-term stability and rarity of all known Central European habitats led to the hypothesis, that the species restricted itself to specific habitat islands, and that it is adapted to these conditions.

This hypothesis can explain historic as well as recent records of $P$. stridulus in Central Europe in isolated habitats (HARZ 1960, HEROLD 1916, HOLST 1986, LUNAU 1940, OSCHMANN 1969, STERNAD 1998). Also in its region of origin, the vast Siberian forest steppe (HARZ 1960, INGRISCH \& KÖHLER 1998), P. stridulus colonises only habitat islands with very rare sets of ecological conditions (BÖNSEL 2003). This leads to the theory of a gradual selection towards colonisation of habitat islands in the current area of distribution. Following this thought, the high number of ovarioles of the species (see RUBTZOV 1934 in INGRISCH and KÖHLER 1998) can be interpreted as a result of saved energy, which are not allocated to flight muscles, but to increased ovarioles production. The same phenomenon can also be found in other species of grasshoppers, inhabiting similar specific habitats (see INGRISCH and KÖHLER 1998). The species does not form metapopulations (BÖNSEL \& RUNZE 2000, JANBEN \& REICH 1998, STERNAD 1998). In contrast, other species occurring in insular habitats like ombrotrophic mires are adapted to isolation of their habitat by forming metapopulations (STERNBERG 1995), thereby preserving their genetic variability. In $P$. stridulus, rather than metapopulation structures, other mechanisms seem to have been selected for. For one, the sex-ratio is shifted towards a higher proportion of males. This phenomenon was interpreted as a sampling error by STERNAD (1998), whereas BÖNSEL \& RUNZE (2000), based on their own and similar observations by other authors (BUCHWEITZ 1993, KOLB \& FISCHER 1994), exclude sampling error and interpret this uneven distribution of sexes as a special adaptation to the existence on habitat islands. $P$. stridulus appears to be adapted to climatic irregularities by prolongation of diapause or by hatching in intervals. This idea is supported by observations of larvae in unusual times of the year (HEMP \& ZEHM 1997, BÖNSEL \& RUNZE 2000). Genetic analysis of nine records of P. stridulus in the northern Frankenalp showed clear differences among them (STERNAD 1998). STERNAD (1998) attributes this to a bottleneck-effect and interprets the isolation of the occurrences as a threat to their existence. In the light of the discussed species' restriction to specific habitat islands and the adaptive consequences thereof (e.g. the females' inability to fly), genetic differentiation would be a consequence.

All this supports the hypothesis presented in this paper. Here data on further ethological and morphological adaptations of Psopbus stridulus to habitat islands will be presented, also supporting the hypothesis.

\section{Study area}

The study area is located in the Biebrza valley in North-eastern Poland (53 $\left.19^{\prime} \mathrm{N} ; 22^{\circ} 34^{\prime} \mathrm{E}\right)$, in one of the last intact percolation mires of Europe (SUCCOW \& JESCHKE 1990) with a total area of 80.000 ha. Here a population of $P$. stridulus inhabits a mineral outcrop covered with sand, which is isolated by the surrounding bog (BÖNSEL \& RUNZE 2000). The study area covers $1.5 \mathrm{ha}, 25 \%$ of it shaded by Quercus petraea and Tilia cordata overstory. $5 \%$ of the 
area are open sandy patches. $70 \%$ are covered by a herb layer which can be subdivided in various sub-layers. Soil type and plant community can be classified as limestone dry grassland. Following the law of similar habitat preference (WALTER \& BRECKLE 1991), habitat conditions are comparable to those of other Central-European populations of P. stridulus (BÖNSEL \& RUNZE 2000).

\section{Materials and methods}

\subsection{Registration of males' and females' behaviour}

The capture-recapture experiments took place in the beginning of August 2000 and 2001 and lasted for 8-10 days in each season (BÖNSEL \& RUNZE 2000). Within the habitat, a grid of $20 \times 20 \mathrm{~m}$ cells was staked out using marked pegs thus facilitating mapping of catches. All males and females of the Polish habitat were caught and marked by writing individual numbers on the males' wings and the females' thoraces. After 2 days, almost all individuals of the habitat were caught once. A maximum of 18 individuals was marked only in the course of the following recapture experiment. In order to monitor night movement pattern, in 2001 altogether 20 females and 30 males were marked additionally with reflecting foil (7610 HIGH GAIN SCOTCHLITE) by wrapping a piece of the self-adhesive foil around the tibia of the hind leg and sticking it together (see OPITZ \& KÖHLER 1997). Individuals marked like this could be detected in the light of a flashlight within distances up to $50 \mathrm{~m}$ even in total darkness. Because of their immobility, the females could be found even after a couple of days still near the place of last capture. Accordingly, they could easily be refound by using torches at night. Using this method, $70 \%$ of the recaptures of females were made at night. In contrast, the males were easy to detect during daytime by their movements, but only accidental recaptures were made at night. Therefore males were caught especially at daytime. Acoustic signals were detected with a bat-detector.

\subsection{Processing of data and statistical analysis}

The informations of the daily grid maps were transfered to a geographical information system (GIS; ArcView), and the distances covered by males and females were calculated. The home ranges of both sexes were determined by drawing the smallest convex polygon which contains all recapture points (JENNRICH and TURNER 1969) and calculating its area. The maximum distances covered were sorted by quantity of recapture. t-Tests were used to compare the means of groups with the same quantity of recaptures between males and females. $t$-Tests were also used to compare the abundances of the different types of sensilla on the antennae between males and females. Separate t-test were conducted for the ventral and the dorsal position.

\subsection{Electron microscopy}

A total of 14 antennae of male and female individuals have been scanned with an electron microscope: 2 males and 2 females from North-eastern Poland, 2 males and 2 females from Central Siberia, 2 males and 2 females from South-western Germany and 1 male and 
1 female from South-eastern Germany. The individuals were killed by ether and preserved in a $4 \%$ solution of glutar aldehyde. An artefact free critical spot drying of the prepared antennae was carried out using K 850 EMTTECH. The conductivity of the preparation was achieved by evaporating with gold in the vacuum (Sputter-Coaters SCD 004). SEM observations were made with a Carl Zeiss DSM 960 A. The preparations were standing vertically on the slide. Thus a dorsal as well as ventral observation of the antennal structure was possible. For living imagines dorsal refers to pointing backwards and ventral to pointing forward with erected antennae.

\section{Results}

\subsection{Spatial distribution and movement pattern of males and females}

In 2000, altogether 187 males and 60 females were recorded, in 2002209 males and 61 females. The rates of recapture of males were approximately equal in both years, whereas the rate of recapture of females increased in 2001 by additional marking with reflecting foil (table 1).

Table 1: No. of individuals (catches), recapture rates, home ranges and distances covered by males and females of Psopbus stridulus in 2000 and 2001

\begin{tabular}{|c|c|c|c|c|}
\hline & \multicolumn{2}{|c|}{2000} & \multicolumn{2}{|c|}{2001} \\
\hline & Males & Ecmales & Males: & Females \\
\hline No. of catches & 187 & 60 & 209 & 61 \\
\hline No. of total recaptures & 73 & 4 & 80 & 28 \\
\hline Percent total recaptures & 40 & 3 & 38 & 46 \\
\hline Nocturnal recaptures & & & 6 & 24 \\
\hline percent nocturnal tecaptures & & & 7,5 & 70,7 \\
\hline one recapture & 56 & 4 & 55 & 19 \\
\hline two recaptures & 16 & & 22 & 5 \\
\hline three recaptures & 1 & & 3 & 2 \\
\hline four recaptures & & & & 2 \\
\hline max. home range $\left(\mathrm{m}^{2}\right)$ & 289,71 & & 386,87 & 84,34 \\
\hline min. home range $\left(\mathrm{m}^{2}\right)$ & 4,8 & & 1,36 & 0,9 \\
\hline mean home range $\left(\mathrm{m}^{2}\right)$ & 80,84 & & 52,67 & 20,18 \\
\hline max. distance covered (m) & 75,56 & 4,5 & 62,04 & 21,45 \\
\hline min. distance covered $(\mathrm{m})$ & 2,24 & 1 & 0,58 & 0,73 \\
\hline mean distance covered (m) & 22,88 & 2,96 & 16,54 & 6,49 \\
\hline
\end{tabular}




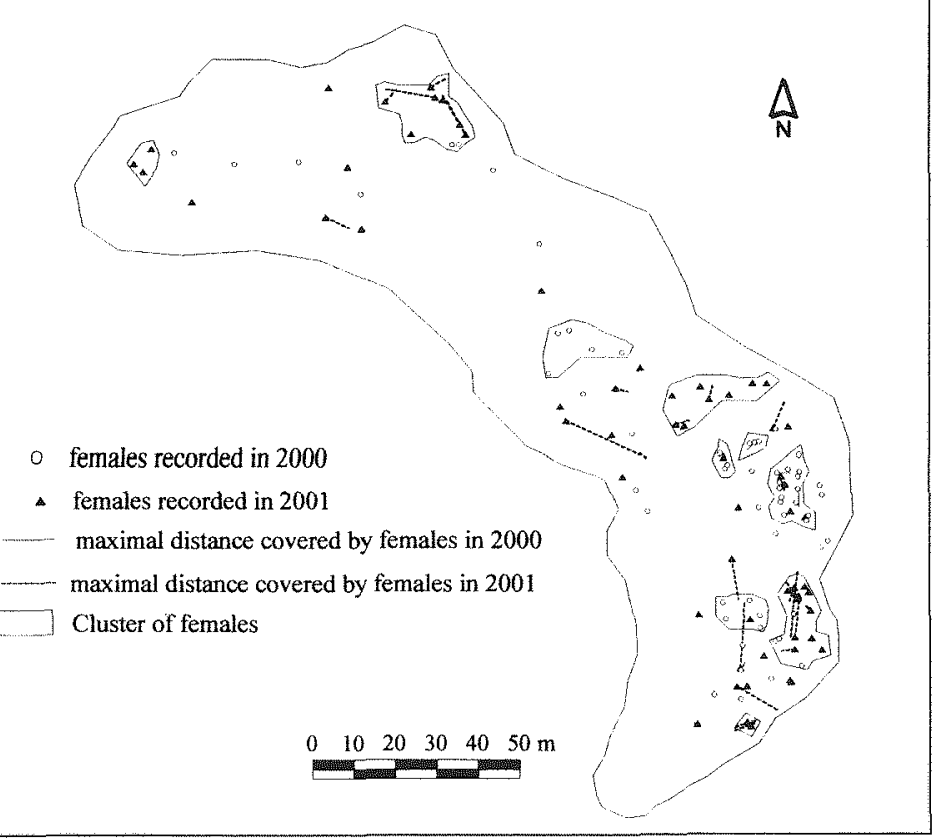

Fig. 1: Spatial distribution and movement pattern of female $P_{\text {sophus stridulus on a }}$ north-eastern Polish habitat island in 2000 and 2001.

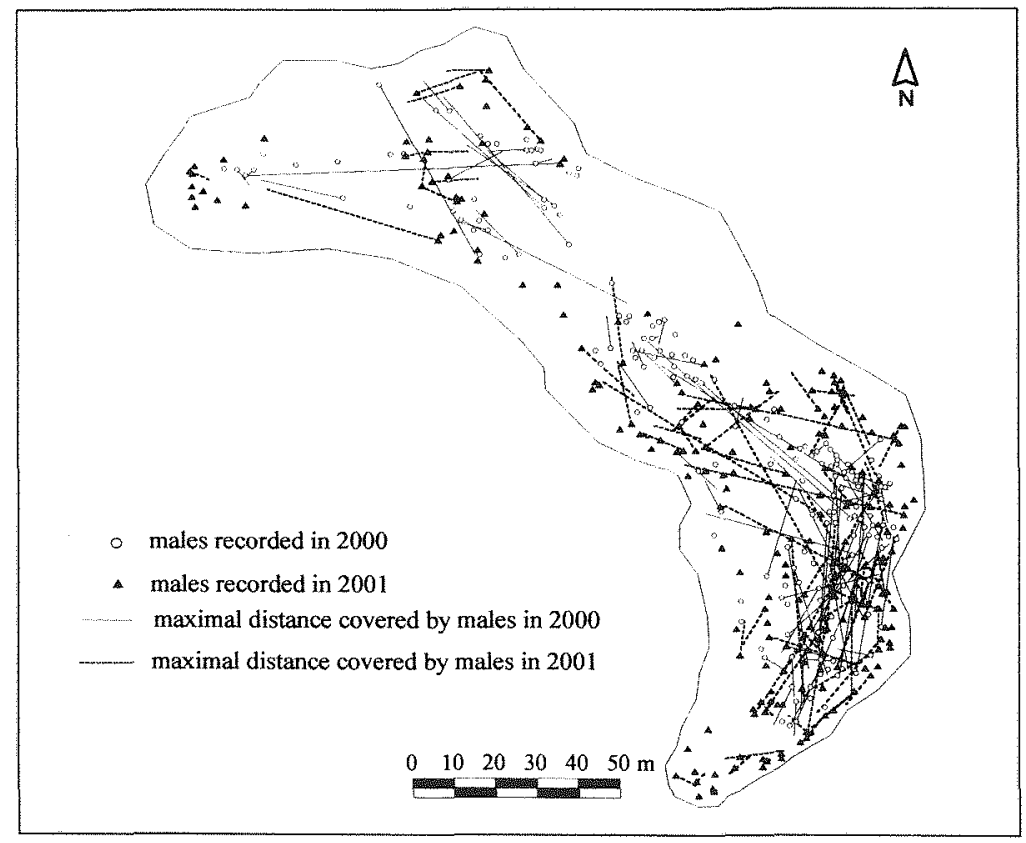

Fig. 2: Spatial distribution and movement pattern of male Psopbus stridulus on a north-eastern Polish habitat island in 2000 and 2001. 


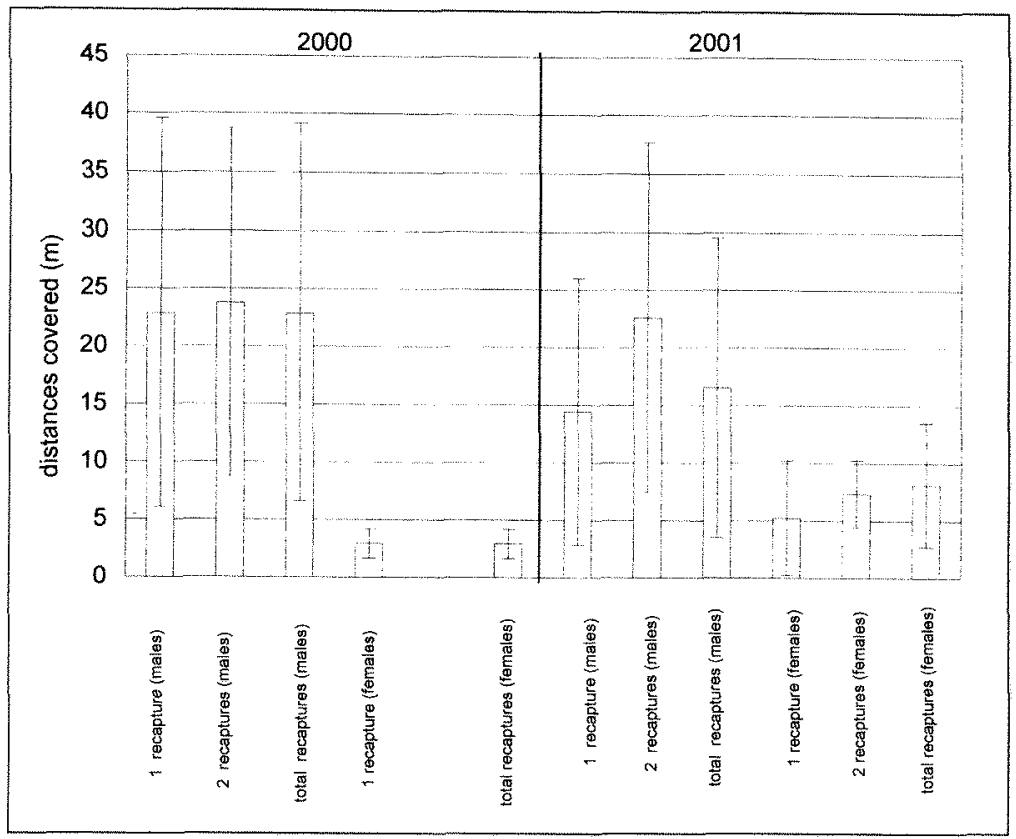

Fig. 3: Means ( $+/$-standard deviation) of distances covered by males and females in 2000 and 2001. Bars indicate groups of 1 and 2 recaptures, respectively, and total recaptures.

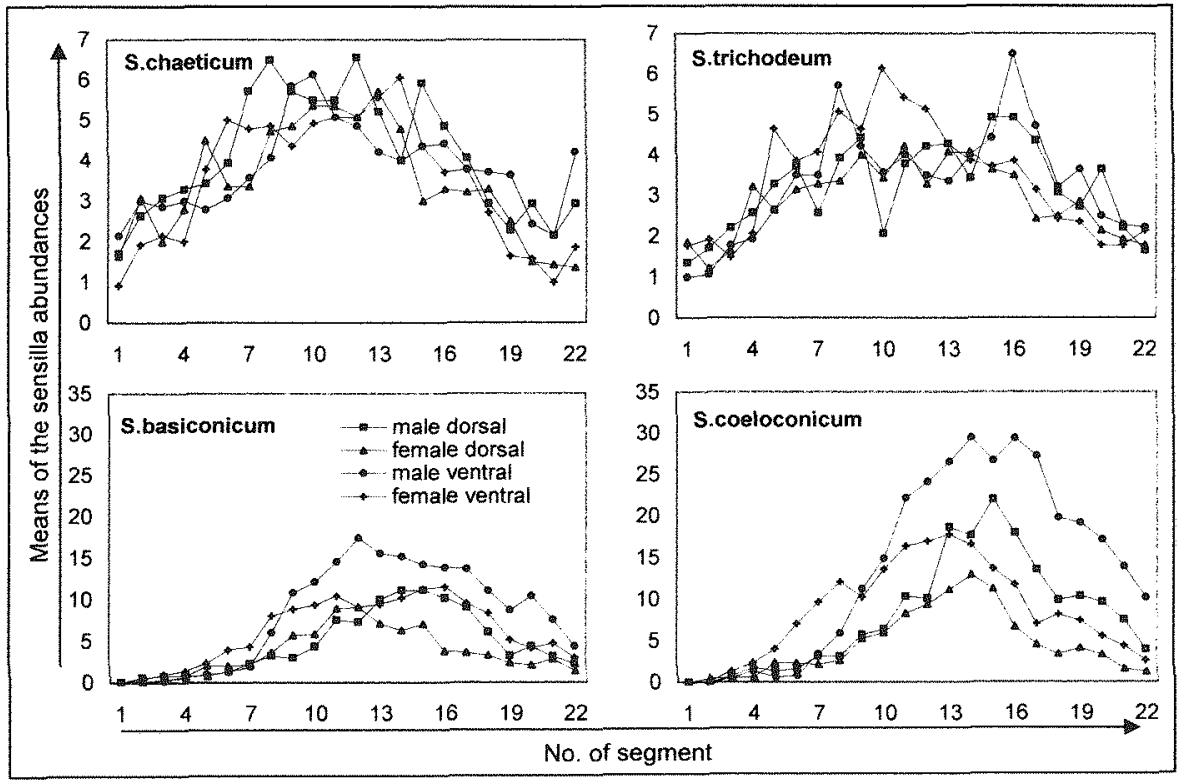

Fig. 4: Abundances of different types of sensilla $(n=14)$ on dorsal and ventral side of antennal segments of Psopbus stridulus. 
Table 2: Sensilla of the dorsal and ventral antennal segments of both sexes of Psophus stridulus

\begin{tabular}{|c|c|c|c|c|c|c|c|c|c|c|c|c|c|c|c|c|c|c|c|c|c|c|c|}
\hline $\begin{array}{l}\text { segments/ } \\
\text { dorsal/male }\end{array}$ & 1 & 2 & 3 & 4 & 5 & 6 & 7 & 8 & 9 & 10 & 11 & 12 & 13 & 14 & 15 & 16 & 17 & 18 & 19 & 20 & 21 & 22 & total \\
\hline $\begin{array}{l}\text { Sensillum } \\
\text { chaeticum }\end{array}$ & 2 & 3 & 3 & 4 & 3 & 3 & 7 & 7 & 8 & 8 & 9 & 10 & 7 & 6 & 8 & 6 & 10 & 4 & 4 & 3 & 2 & 2 & 119 \\
\hline $\begin{array}{l}\text { Sensillum } \\
\text { trichodeun }\end{array}$ & 2 & 2 & 2 & 2 & 1 & 3 & 2 & 4 & 4 & 5 & 3 & 3 & 7 & 3 & 7 & 9 & 8 & 3 & 3 & 7 & 3 & 3 & 86 \\
\hline $\begin{array}{l}\text { Sensillum } \\
\text { basiconicum }\end{array}$ & & 2 & 3 & 2 & 2 & 2 & 1 & 1 & 2 & 1 & 3 & 4 & 5 & 16 & 17 & 11 & 17 & 9 & 4 & 7 & 7 & 2 & 118 \\
\hline $\begin{array}{l}\text { Sensillum } \\
\text { coeloconicum }\end{array}$ & & & & & & & & & 4 & 3 & 8 & 11 & 16 & 17 & 21 & 18 & 18 & 9 & 7 & 11 & 7 & 4 & 154 \\
\hline \multicolumn{24}{|l|}{$\begin{array}{l}\text { segments } \\
\text { dorsal/fenale }\end{array}$} \\
\hline $\begin{array}{l}\text { Sensillum } \\
\text { chacticum }\end{array}$ & 2 & 3 & 1 & 2 & 1 & 1 & 2 & 3 & 6 & 5 & 5 & 4 & 5 & 3 & 2 & 8 & 6 & 5 & 4 & 3 & 3 & 5 & 79 \\
\hline $\begin{array}{l}\text { Sensillum } \\
\text { trichodeum }\end{array}$ & 5 & 5 & 4 & 5 & 2 & 5 & 7 & 7 & 12 & 8 & 11 & 10 & 10 & 13 & 8 & 10 & 10 & 7 & 6 & 11 & 9 & 4 & 169 \\
\hline $\begin{array}{l}\text { Sensillum } \\
\text { basiconicum }\end{array}$ & & 2 & 2 & 3 & & 1 & 4 & 3 & 5 & 5 & 9 & 9 & 10 & 7 & 7 & 10 & 8 & 3 & 4 & 1 & & & 93 \\
\hline $\begin{array}{l}\text { Sensillum } \\
\text { coeloconicutn }\end{array}$ & & & & & & & & & 3 & 3 & 8 & 9 & 15 & 8 & 8 & 9 & 5 & 5 & 6 & 2 & 3 & 4 & 88 \\
\hline \multicolumn{24}{|l|}{$\begin{array}{l}\text { segments } / \\
\text { ventral } / \mathrm{male}\end{array}$} \\
\hline $\begin{array}{l}\text { Sensillum } \\
\text { chaeticum }\end{array}$ & 5 & 4 & 5 & 3 & 4 & 1 & 3 & 6 & 11 & 11 & 7 & 9 & 6 & 4 & 9 & 3 & 5 & 4 & 2 & 1 & 5 & 8 & 116 \\
\hline $\begin{array}{l}\text { Sensillum } \\
\text { trichodeum }\end{array}$ & 1 & & 2 & & 2 & 4 & 1 & 3 & 3 & 4 & 2 & 2 & 3 & & 2 & 17 & 6 & 1 & 4 & 2 & 2 & 3 & 64 \\
\hline $\begin{array}{l}\text { Sensillum } \\
\text { basiconicum }\end{array}$ & & & 2 & 2 & 2 & 1 & 2 & 7 & 23 & 17 & 25 & 28 & 10 & 7 & 12 & 11 & 8 & 4 & 7 & 7 & 7 & 6 & 188 \\
\hline $\begin{array}{l}\text { Sensillum } \\
\text { coeloconicum }\end{array}$ & & & 1 & 1 & & & 3 & 11 & 27 & 25 & 22 & 29 & 30 & 19 & 31 & 38 & 28 & 8 & 20 & 13 & 15 & 20 & 341 \\
\hline \multicolumn{24}{|l|}{$\begin{array}{l}\text { segments/ } \\
\text { ventral/fenale }\end{array}$} \\
\hline $\begin{array}{l}\text { Sensillum } \\
\text { chacticum }\end{array}$ & 1 & 1 & 2 & 1 & & 2 & & 1 & 2 & 4 & 6 & 2 & 3 & 2 & & 3 & 2 & 2 & 2 & 2 & 3 & 1 & 42 \\
\hline $\begin{array}{l}\text { Sensillum } \\
\text { trichodeurn }\end{array}$ & 2 & 4 & & 4 & 4 & 3 & 7 & 9 & 7 & 7 & 5 & 4 & 2 & 4 & 5 & 6 & 3 & 2 & 3 & 1 & 6 & 5 & 93 \\
\hline $\begin{array}{l}\text { Sensillum } \\
\text { basiconicumn }\end{array}$ & & 4 & 2 & 3 & & 2 & & 11 & 18 & 24 & 30 & 32 & 26 & 22 & 21 & 25 & 11 & 7 & 4 & 4 & 7 & 3 & 252 \\
\hline $\begin{array}{l}\text { Sensillum } \\
\text { oeloconicum }\end{array}$ & & 2 & 2 & 1 & & 1 & 3 & 15 & 8 & 18 & 20 & 38 & 27 & 30 & 23 & 20 & 10 & 16 & 13 & 3 & & & 248 \\
\hline
\end{tabular}

The north-western part of the study area was less frequented by the imagines in both years (fig. 1,2). This is attributed to shading by groups of Quercus petraea and Tilia cordata. Any preferences for other vegetation structures were not found. The males proved to be the more active gender in all observations: In both years, the maximum distances covered by the males were significantly larger than those of the females $(\mathrm{p}<0.1)($ fig. $1 / 2 / 3 ;$ tab. 1$)$. 


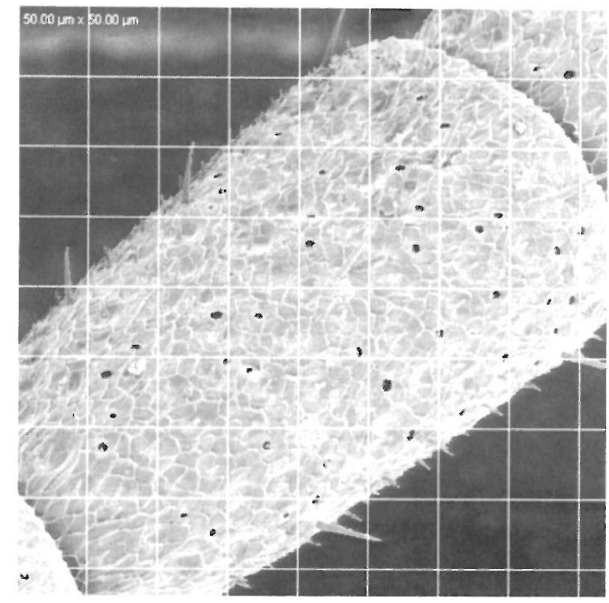

Fig. 5: Ventral view on $9^{\text {th }}$ antennal segment of Psophus stridulus male

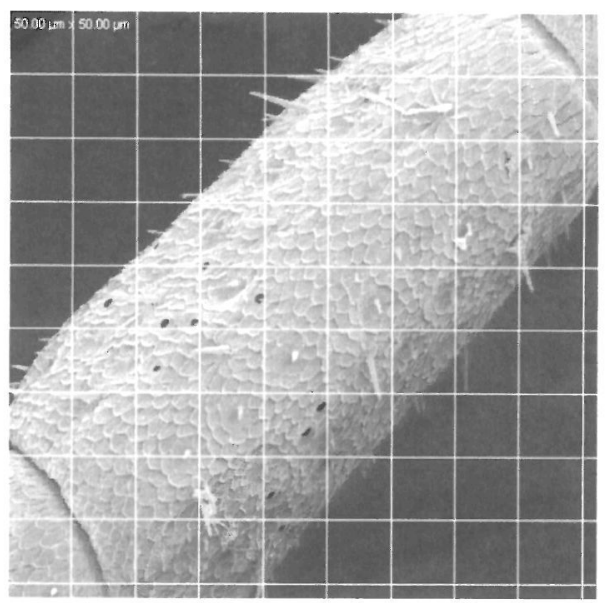

Fig. 6: Ventral view on $9^{\text {th }}$ antennal segment of Psopbus stridulus female

Due to the high activity of the males, their trajectories crossed frequently. Territories with defined borders did not exist. The females hardly moved at all, but stayed in a narrow corridor during the whole time of the studies, partly in dense clusters (fig. 1). Highest activity of males was observed near clusters of females (fig. 2). Males moved in about $85 \%$ of the observations by crawling and in $15 \%$ by flying. Flights are rarely accompanied by rattling. Rattling did not influence the females' behaviour, they stayed passive and even hid when high numbers of males were present. In 2000, 4, and in 2001, 2 matings were observed. The male approached the female silently and mated with it. Mating was observed even in light rain. In rainy weather no acoustic signals were heard at all. No acoustic signals from females were recorded at any time of the study.

\subsection{SEM structure of the antennae}

The four typical forms of sensilla of the Orthoptera, Sensillum chaeticum, S. trichodeum, S. basiconicum and S. coeloconicum, were found on all 22 segments of the antennae (see OCHIENG et al. 1998). Highest abundances of all types of sensilla were found on the ventral sides of the antennae. Sensillum chaeticum and S. trichodeum showed an almost regular distribution over all segments of the antennae in both sexes (fig. 4), without significant differences in their abundances between males and females ( $p>0.01)$. S. basiconicum and $\mathrm{S}$. coeloconicum were the most frequent sensilla, their highest densities could be found on the ventral side of the $10^{\text {th }}$ to $22^{\text {nd }}$ segment (fig. 4 , table 2). Higher densities of Sensillum basiconicum were found in males than in females, with a significant difference on the ventral side of the antenna $(p<0.01)$.

Sensilla coeloconica were found on the $6^{\text {th }}$ to $22^{\text {nd }}$ segment. Here the males showed significantly higher densities than the females on the dorsal as well as on the ventral side of the antennae $(p<0.01)($ fig. $5 / 6)$. 


\section{Discussion}

According to the movement patterns of males and females (see also BUCHWEITZ 1993, KOLB \& FISCHER 1994, JANBEN \& REICH 1998), individuals neither occupy nor defend defined territories. This is indicated by frequent crossing of the males' trajectories. Rattling is a rare event. JACOBS (1953) interprets rattling as part of courtship. If so, the females would have to approach a possible winner in contest, or at least the loser among the males would have to retreat. However, this was not observed in both years of the study. Therefore rattling is not considered to be part of courtship or competition. The matings observed in rain support the theory that finding of females is not due to acoustic signals. The scarcity of the females and their passivity are considered to be the major reason for the high activity of the males, forcing them to scan the habitat repeatedly for females. The rattle may stimulate the females to excrete pheromones, thereby attracting the males. This stimulation could be the reason, why from time to time some males rattle instinctively, thereby causing the females to reveal their hidden position by excretion of pheromones. This mechanism of finding females by their pheromones is known from few other species of grasshoppers (see BLANEY \& SimMONDS 1990, SiddiQI \& KHAN 1981, WhitMan 1982 and 1990).

The high abundance of Sensilla coeloconica in male P. stridulus (fig. 4), which serve for detection of chemical stimuli (OCHIENG et al. 1998), leads to the hypothesis that their function is perception of females ready to mate. A similar dimorphism of sensilla is also known from another species of grasshoppers (BLAND 1982) and numerous species of butterflies (KEIL et al. 2001, STEINBRECHT 1999). However, further investigations on the functions of the different types of sensilla are necessary, since it is possible that there are differences in function between species and also between the sexes (KEIL et al. 2001, OBENG-OFORI et al. 1994, OCHIENG et al. 1998, STEINBRECHT 1998, STEINBRECHT et al. 1996).

The genetic cohesion, which is selected for the specific biotope, has to be protected from destruction e.g. by gene drift (MAYR 1967). This is possible only if as much genetic material as possible is taken along to the next generation. In $P$. stridulus, the females seem to be responsible for passing on as many genes as possible in multiple ways. Short-time excretions of pheromones in small doses reveal their hidden positions to the males, but the time limitation of the signal prevents attraction of too many males at a time. A male being by chance close to a female excreting pheromones can find it and mate with it. Afterwards it will leave, unaware of the other females usually hidden close by (fig. 1), and continue scanning the habitat for other females. The female can attract another male by further excretion of pheromones after some time. The clusters of females increase the chance, that more than one male perceives the signal and that the group of females is found by at least one of the males attracted.

Further it is known, that $P$. stridulus is one of the grasshopper species able to store sperm (REINHARDT \& JENTZSCH 1999, REINHARDT 2000). Considering the high probability of matings with different males, this mechanism increases the number of possible gene combinations in next generation. This phenomenon was described for numerous species including humans (COOK \& GAGE 1995, BAKER \& BELLIS 1993, BIRKHEAD \& MOLLER 1998, GAGE \& BAKER 1991, GAGE \& Bernard 1996, PARKER 1970, PARKER et al. 1990, SIMMONS 1987). The behaviour of the females thereby serves for increasing and maintaining the existing genetic variability in the following generations. 
In this context also investment of females in higher proportions of male offspring has to be discussed. The high mobility of the males increases the chance of mating with different females, thereby passing on many genes to the following generations. Sensu DAWKINS (1976), male $P$. stridulus are typical players, setting high stakes and taking high risks for the survival of their genes. In contrast, the females are careful investors, trying to minimise their risks and maximising the chance to pass on as many genes as possible to the next generation. These strategies can be the result of habitat isolation, or, on the other hand, can have made the colonisation of habitat islands possible at all (see KANESHIRO 1976/1980). Precision of adaptations went so far that the mayor part of flight muscles were sacrified in favour of increased ovariole production.

Further studies should explore whether the females in fact announce their readiness for mating by pheromones, and whether this is the reason for the sex dimorphism of the antennal structures. Also, the physiological plasticity of the females, enabling directed investment in higher proportions of male offspring (see TELFORD \& DANGERFIELD 1990), need further examination.

\section{Acknowledgements}

I would like to thank to the Centre of Electron Microscopy of the Medical Faculty at the Rostock University for technical co-operation. I also thank PD Dr. G. Köhler for his many practical hints and for the reflecting foil. I acknowledge the critical review of the manuscript drafts by Prof. Dr. H. Zucchi and Prof. Dr. R.A. Steinbrecht, as well as the supports of N. Hobbhahn, M. Runze and Dr. D. Hönig.

\section{References}

COOK, P. A. \& GAGE, M. J. G. 1995: Effects of tisks of sperm competition on the number of eupyrene and apyrene sperm ejaculated by the moth Plodia interpunctella (Lepidoptera: Pyralidae). - Behav. Ecol. Sociobiol. 36: 261-268.

BAKER, R. R. \& BELLIS, M. B. 1993: Human sperm competition: ejaculate manipulation by females and a function for the female orgasm. - Anim. Behav. 46: 887-909.

Birkhead, T. H. \& Moller, A. P. 1998: Sperm competition and sexual selection. - Academic Press, London.

BLAND, R. G. 1982: Morphology and distribution of sensilla on the antennae and mouthparts of Hypocblora alba (Orthoptera: Acrididae). - Ann. Entomol. Soc. Am. 75: 272-283.

BLANEY, W. M. \& SIMMONDS, M. S. J. 1990: The chemoreceptors. 1-37 pp. - By: CHAPMAN, R. F. \& JOERN, A. (ed.) Biology of grasshoppers. A wiley-Interscience publication. - New York, Chichester, Brisbane, Toronto, Singapore.

BÖNSEL, A. 2003: Heuschreckenbeobachtungen und Notizen ökologischer Standortparameter aus Westsibirien und dem Altaigebirge. - Articulata 18 (1): 35-50.

BÖNSEL, A. \& RUNZE, M. 2000: Ein Habitat der Rotflügeligen Schnarrschrecke (Psopbus stridulus L. 1758) im nordöstlichen Polen. - Articulata 15 (1): 1-13.

BUCHWETTZ, M. 1993: Zur Ökologie der Rotflügeligen Schnarrschrecke (Psophus stridulus) unter besonderer Berücksichtigung der Mobilität, Populationsstruktur und Habitatwahl - Articulata 8 (2): 39-62.

DAWKINS, R. 1976: The selfish gene. - Oxford University Press, Oxford.

DETZEL, P. 1998: Die Heuschrecken Baden-Württembergs. - Ulmer, Stuttgart.

GAGE, A. R. \& BERNARD, C. J. 1996: Male crickets increase sperm number in relation to competition and females size. - Behav. Ecol. Sociobiol. 38: 349-353. 
GAGE, M. J. G. \& BAKER, R. R. 1991: Ejaculate size varies with sociosexual situation in an insect. - Ecol. Entomol. 16: 331-337.

HARZ, K. 1960: Geradflügler. - In: DAHL, F. (ed.): Die Tierwelt Deutschlands und der angrenzenden Meeresteile. 46. Teil. - Gustav Fischer Verlag, Jena.

HEMP, C. \& ZEHM, A. 1997: Eine zweite Larvenschlupfwelle bei Heuschrecken - ein Beitrag zur Populationsbiologie von Psopbus stridulus und Myrmeleotettix maculatus. - Articulata 12 (2): 123-129.

HER, R. \& RrTSCHEL-KANDEL, G. 1992: Heuschrecken als Zeigerarten des Naturschutzes in Xerothermstandorten des Saaletales bei Machtilshausen. - Articulata 7: 77-100.

HEROLD, W. 1916: Zum Vorkommen von Psophus stridulus. - Zeitschr. wissenschaft1. Insekten Biologie 12: 318-319.

HOIST, K. T. 1986: The Saltatoria of Northern Europe. - Fauna Entomolagica Scandinavica, Volume 16.

INGRISCH, S. \& KÖHLER, G. 1998: Die Heuschrecken Mitteleuropas. Die Neue Brehm Bücherei Bd. 629. Westarp Wissenschaften, Magdeburg.

JACOBS, W. 1953: Verhaltensbiologische Studien an Feldheuschrecken. - Zeitschrift für Tierpsychologie, Beiheft 1: 1-228.

JANBEN, B. \& REICH, M. 1998: Zur Populationstruktur und Mobilität von Psophus stridulus in einer alpinen Wildflußlandschaft. - Articulata 13 (2): 121-125.

JENNRICH, R. J. \& TURNER, F. B. 1969: Measurement of non-circular home range. - J. Theor. Biol., London, 22: 227-237.

KANESHIRO, K. Y. 1976: Ethological isolation and phylogeny in the plantibia subgroup of Hawaiian Drosophila. - Evolution 30: 740-5.

KANESHIRO, K. Y. 1980: Sexual isolation, speciation and the direction of evolution. - Evolution 34: 437-44.

KeIL, T. A.; HARTLIEB, E.; BOCK, C. \& STEINBRECHT, R. A. 2001: Die Mikrowelt der Insektennasen, Antennen, Sensillen und Duftmoleküle. - Naturwissenschaftliche Rundschau 54 (10): 519-525.

KOLB, K. H. \& FISCHER, K. 1994: Populationsgröße und Habitatnutzung der Rotflügeligen Schnarrschrecke (Psopbus stridulus) im NSG Steinberg und Weinberg/Bayerische Rhön. - Articulata 9 (2): 25-36.

LuNAU, C. 1940: Zur Heuschreckenfauna Mecklenburgs. - Arch. Ver. Freunde Naturg. Mecklb. NF 15: 104-110.

MAYR, E. 1967: Artbegriff und Evolution. - Paul Parey Verlag, Hamburg, Berlin.

Obeng-Ofori, D.; NJagi, P. G. N.; Torto, B.; Hassanali, A. \& Amiani, H. 1994: Sex differentiation studies relating to releaser aggregation pheromones of the desert locust, Schistocera gregaria. - Entomol. Exp. Appl. 73: 85-91.

OCHIENG, S. A.; HALLBERG, E. \& HANSSON, B. S. 1998: Fine structure and distribution of antennal sensilla of the desert locust, Schistocerca gregaria (Orthoptera: Acrididae). - Cell Tissue Res. 291: 525-536.

OPITZ, S. \& KörLER, G. 1997: Wie nutzen Feldheuschrecken (Caelifera: Gomphcerinae) ihr Habitat? Mitteilungen der Deutschen Gesellschaft für Allgemeine Angewandte Entomologie 11: 619-622.

OSCHMANN, M. 1969: Faunistisch-ökologische Untersuchungen an Orthopteren im Raum von Gotha. Hercynia N. F. 6: 115-168.

PARKer, G. A. 1970: Sperm competition and its evolutionary consequences in the insect. - Biol. Rev. 45: 525-567.

PARKer, G. A.; SIMMONS, L. W. \& KIRK, H. 1990: Analysing sperm competition data: simple models for predicting mechanism. - Behav. Ecol. Sociobiol. 27: 55-65.

REINHARDT, K. 2000: Spermienzahlen heimischer Acrididae. - Articulata 15 (1): 113-120.

REINHARDT, K. \&JENTZSCH, A. 1999: Lebensdauer, Eizahl und Dauer der Speicherung lebensfähiger Spermien bei Weibchen der Italienischen Schönschrecke (Calliptamus italicus L.). - Articulata 14 (2): 199-204.

SIDDIQI, J. I. \& KHAN, M. A. 1981: The secretion and perception of a sex pheromone in the grasshopper Hieroglyphus nigrorepletus BOLIVAR (Orthoptera: Acrididae). - Acrida 10: 233-242.

SimMONS, L. W. 1987: Sperm competition as a mechanism of female choice in the field cricket, Gryllus bimaculatus. - Behav. Ecol. Sociobiol. 21: 197-202. 
STEINBRECHT, R. A. 1998: Bimodal thermo- and hygrosensitive sensilla. - Microscopic anatomy of invertebrates 11B: 405-422.

STEINBrechT', R. A. 1999: Olfactory receptors: 155-176. - By: Eguchi, E. \& TOMINAGA, Y. (Ed.) Atlas of arthropod sensory receptors, Dynamic morphology in relation to function. - Springer Verlag, Tokyo.

STEINBRECHT, R. A.; LAUE, M.; MAIDA, R. \& ZIEGELBERGER, G. 1996: Odorant-binding proteins and their role in the detection of plant odours. - Entomologia Experimentalis et Applicata 80: 15-18.

STERNAD, H. 1998: Verbreitung und genetische Populationsstruktur von Psophus stridulus (Orthoptera: Acrididae) auf der Nördlichen Frankenalb. - Diplomarbeit Universität Saarland, Erlangen.

STERNBERG, K. 1995: Regulierung und Stabilisierung von Metapopulationen bei Libellen am Beispiel Aesbna subarctica elisabetae DJAKONOV im Schwarzwald. - Libellula 14 (1/2): 1-39.

SUCCOW, M. \& JESCHKE, L. 1990: Moore in der Landschaft. - Urania Verlag, Leipzig, Jena, Berlin.

TELFORD, S. R. \& DANGerfieLD, J. M. 1990: Manipulation of the sex ratio in the tropical millipede Alloporus uncinatus: a test of the copulatory guarding hypothesis. - Animal. Behav. 40: 984-986.

VÄIsänen, R.; SOMERMA, P.; KUUSSAARI, M. \& NiEMINEN, M. 1991: Bryodema tuberculata and Psophus stridulus in southwestern Finland. - Entomologica Fennica 2 (1): 27-32.

VARGA, Z. 1997: Trockenrasen im pannonischen Raum: Zusammenhang der physiognomischen Struktur und der floxistischen Komposition mit den Insektenzönosen. - Phytocoenologia 27 (4): 509-571.

VOSSEN, B. \& PIPER, W. 1996: Wiederfund der Rotflügeligen Schnarrschrecke - Psopbus stridulus für Brandenburg. - Articulata 11 (1): 103-108.

WALTER, H. \& BRECKLE, S. W. 1991: Ökologie der Erde. Band 1. UTB.

WHITMAN, D. W. 1982: Grasshopper sexual pheromone: a component of the defensive secretion in Taeniopoda eques. - Physiol. Ent. 7: 111-115.

WHITMAN, D. W. 1990: Grasshopper chemical communication. 357-391. - By: CHAPMAN, R. F. \& JOERN, A. (ed.) Biology of grasshoppers. A wiley-Interscience publication. - New York, Chichester, Brisbane, Toronto, Singapore.

\section{Anschrift des Verfassers:}

ANDRÉ BÖNSEL

Vasenbusch 15

D-18337 Gresenhorst

Germany

e-mail: Andre.Boensel@gmx.de 